\title{
IMPLEMENTASI LOGIKA FUZZY PADA PEMBUATAN KARAKTER MUSUH UNTUK GAME SINGLE FIGHTER BERPLATFORM ANDROID
}

\author{
Fajar Mitasari ${ }^{1)}$, Wawan Laksito YS ${ }^{2)}$, Sri Siswanti ${ }^{3)}$ \\ 1,2,3) Program Studi Teknik Informatika, STMIK Sinar Nusantara Surakarta \\ ${ }^{1)}$ poonievam@gmail.com, ${ }^{2)}$ wlaksito@yahoo.com, ${ }^{3)}$ syswanty@gmail.com
}

\begin{abstract}
This adventure game tells the story of an elephant who struggles to save his son from enemy prisoners. Elephants should be able to beat all three enemies, namely monkeys, wolves, and kingkong to be able to find his son. In the course of fighting the enemy will be no relief in the form of bombs and weapons are power ups in the form of apples to increase the number of lives player. The behavior of the enemy characters in this game are designed with the application of fuzzy logic Sugeno method. Each enemy by artificial intelligence has a health status (lives), ammo (the number of stones to attack the player) and distance (distance to the player during the attack). This game has a rule of implementation Sugeno Fuzzy Logic method for calculating the value of output behavior of the enemy in attacking player. The system design of the game is using the storyboard that contains a description of the story of each scene and any component material that will be used. Then the algorithm implementation using the Unity game development software. For game development, programming language used is $C$ \# of Unity. The results of this study are the Application Game "Single Fighter" that has succeeded in publishing in the Google Play Store are made of Unity game engine, side-scrolling genre game, and the android platform. From the application of fuzzy logic in this game also has gone well, where there are 41 types of enemy attackers\%, 36\% type of archer-distance and $87 \%$ of type giant enemy very aggressive in attacking player.
\end{abstract}

Kata Kunci: Game, Logika Fuzzy, Sugeno, Unity, Android

\section{PENDAHULUAN}

Game merupakan salah satu sarana hiburan yang banyak diminati oleh masyarakat. Pada mulanya game hanya dimainkan di komputer dan console tetapi sekarang sudah memasuki era mobile game. Game yang akan dikembangkan ini berplatform Android yang dapat diunduh secara gratis melalui Google Play Store.

Game yang berjudul "Single Fighter" pada penelitian ini bercerita tentang perjuangan seekor Gajah yang menyelamatkan anaknya dari tawanan musuh atau enemy. Latar kejadian permainan ini berada di sebuah hutan dan terdapat banyak monyet, srigala serta kingkong yang menjadi musuh gajah. Jika sang gajah mampu mengalahkan semua musuhnya maka dia akan bertemu dengan anaknya yang ditawan jauh didalam hutan. Untuk menciptakan suasana hidup dalam game ini, aksi para enemy harus diberi kecerdasan buatan dengan Logika Fuzzy menggunakan metode Sugeno.

Pada karakter musuh akan diberikan kecerdasan buatan berdasarkan variabel yang sudah ditentukan yaitu health point musuh, amunisi dan distance antara musuh dengan player. Penerapan logika fuzzy pada permainan ini menghasilkan output yaitu musuh memiliki perilaku untuk menyerang player. 
Pada penelitian lain Logika Fuzzy Sugeno juga digunakan untuk menentukan peran robot dalam game sepak bola yang menggunakan 2 variabel yaitu sudut dan jarak terhadap bola dan mengatur perilaku musuh dalam game bertipe Action-RPG yang menggunakan 3 variabel yaitu life, jumlah panah, dan range distance (Purba, 2013).

Hasil dari kedua penelitian tersebut memiliki keberhasilan 90\% dari 10 percobaan yang berhasil mengoptimasi penentuan peran robot dalam game sepak bola dan pada game "Song of Ruination 2" logika Fuzzy Sugeno berjalan dengan baik dimana tiap karakter musuh memiliki prosentase tingkat agresif saat menyerang player sebesar 45\% untuk tipe penyerang, 49\% untuk tipe pemanah, dan 89\% untuk tipe boss (Al Hasmy, 2011 ).

Dari hasil review tentang penerapan Logika Fuzzy Sugeno terhadap penentu peran robot maupun perilaku karakter musuh dalam game diatas, penulis berkeinginan untuk mengembangkan penerapan tersebut dalam game adventure "Single Fighter" berplatform Android dengan genre side scrolling game.

\section{TINJAUAN PUSTAKA}

\subsection{Logika Fuzzy Sugeno}

Teori himpunan logika samar dikembangkan oleh Prof. Lotfi Zadeh pada tahun 1965. Zadeh berpendapat bahwa logika benar dan salah dalam logika konvensional tidak dapat engatasi masalah gradasi yang berada pada dunia nyata. Untuk mengatasi masalah gradasi yang tidak terhingga tersebut, Zadeh mengembangkan sebuah himpunan fuzzy. Tidak seperti logika boolean, logika fuzzy mempunyai nilai yang continue. Kondisi samar dinyatakan dalam derajat dari suatu keanggotaan dan derajat dari kebenaran. Oleh sebab itu sesuatu dapat dikatakan sebagian benar dan sebagian salah pada waktu yang sama.

Sebelum menjadi sebuah keputusan, maka ada beberapa tahap proses fuzzy, yaitu

- Fuzzyfikasi : Mencari derajat keanggotaan dari input fuzzy yang memenuhi fuzzy rule

- Operasi Logika Fuzzy : menggunakan fungsi AND, yaitu mengambil nilai MAX dari derajat keanggotaan setiap input fuzzy.

- Implikasi : Mendapatkan keluaran dari fuzzy rule menggunakan fungsi MIN.

- Agregasi : Mengkombinasikan keluaran semua fuzzy rule menjadi fuzzy set tunggal dengan menggunakan fungsi Max.

- Defuzzyfikasi : Masukkan fuzzy set (dalam hal ini fuzzy set hasil agregasi) dan keluaran sebuah bilangan tunggal.

Model Sugeno merupakan fuzzy yang menggambarkan dengan "IF-THEN" yaitu sebuah aturan yang mewakili hubungan input atau output lokal dari sistem nonlinear. Dalam metode Sugeno, output sistem berupa konstanta atau persamaan linier. Metode ini diperkenalkan oleh Takagi-Sugeno Kang pada 1985. Berikut adalah bentuk umum model fuzzy Sugeno (Kusumadewi, 2010).

$$
\text { if }(x 1 \text { is } A 1) \ldots . .(x n \text { is } A n \text { then } z=f(x, y))
$$




\subsection{Unity 3D}

Dalam pembuatan aplikasi ini menggunakan software Unity 3D karena Unity 3D mendukung bahasa pemrograman C\#. Bagian projects meliputi semua elemen dalam game yang dibuat, seperti models, scripts, levels, dan menu. Unity lebih tepat dijelaskan sebagai software yang mengembangkan video game atau disebut juga game engine (Watkins, 2011 ).

\subsection{Android}

Sistem operasi berbasis android dipilih karena bersifat open source, jadi sangat memungkinkan penggunanya untuk membuat software sendiri. Pengertian sistem operasi android merupakan sebuah sistem operasi untuk perangkat mobile berbasis Linux yang dikeluarkan oleh Google Inc pada bulan November 2007 (Wahana Komputer, 2013).

\section{METODE PENELITIAN}

Untuk memperoleh hasil penelitian berupa game bergenre side scrolling game dari implementasi logika fuzzy, maka digunakan beberapa metode penelitian sebagai berikut :

\subsection{Pre Production}

Tahap pre-production adalah tahap dalam pembuatan game yang berfokus pada ide dan konsep pengembangan game. Tujuan dari proses ini adalah untuk memperoleh gambaran jelas tentang game yang akan dibuat serta membantu dalam menentukan target serta deadline dalam proses pembuatan game.

Pada tahap ini terdiri dari :

- Penulisan Story

- Pembuatan Storyboard

- Melakukan Desain Game

- Mempersiapkan Audio

\subsection{Production}

Pada proses ini terdapat tahapan untuk merubah konsep menjadi realita, dari ide yang sudah dipikirkan menjadi gameplay pada layer. Tahap pengumpulan segala kebutuhan produksi yang telah dipersiapkan dari tahap Pre Production akan diolah lebih lanjut menggunakan software Unity 3D. Semua tool dan bahan yang telah disediakan harus kompatibel, supaya proses ini dapat diterapkan menggunakan Logika Fuzzy Sugeno.

\subsection{Post Production}

Setelah game selesai dibuat, dilakukan beberapa pengujian atau testing. Untuk menguji hasil perhitungan Logika Fuzzy dalam membangun karakter musuh akan dilakukan perhitungan manual yang dicocokkan dengan hasil output otomatis pada field dalam software Unity. Untuk menguji fungsionalitas dari game yang telah dibangun menggunakan Blackbox, sedangkan untuk menguji game tersebut support diberbagai jenis smartphone maka dilakukan uji device ke perangkat seperti tablet dan beberapa smartphone berbeda merk, kemudian untuk menguji kelayakan dari game tersebut dilakukan penyebaran Kuesioner. 
IV. HASIL DAN PEMBAHASAN

4.1 Pre-Production

a. Storyboard

Tabel 1. Storyboard Game

\begin{tabular}{|c|c|c|}
\hline No & Scene & Keterangan \\
\hline 1 & 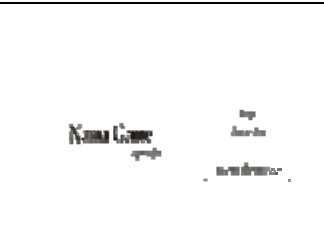 & $\begin{array}{l}\text { Splash Screen } \\
\text { Scene pertama berisi splash screen yang } \\
\text { menampilkan judul game, copyright, dan logo } \\
\text { almamater pembuat. }\end{array}$ \\
\hline 2 & 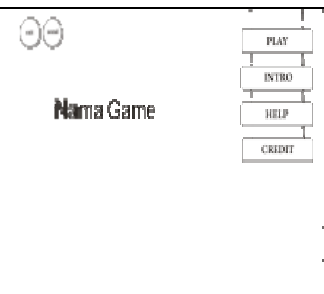 & $\begin{array}{l}\text { Main Menu } \\
\text { Rancangan tampilan main menu berisi } 4 \text { menu utama } \\
\text { dan } 2 \text { tombol untuk setting sound dan tombol keluar } \\
\text { aplikasi game ini. } \\
\text { Sound yang digunakan pada scene ini adalah Jungle } \\
\text { Bit Jukebox. }\end{array}$ \\
\hline 3 & 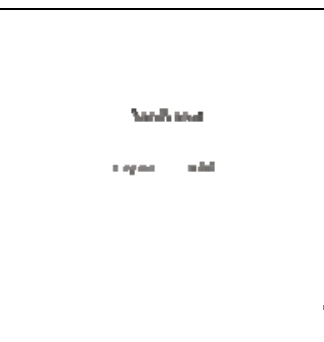 & $\begin{array}{l}\text { Credit Scene } \\
\text { Tidak di isi dengan audio } \\
\text { Berisi : } \\
\text { - Nama pembuat } \\
\text { - Software pembuatan game } \\
\text { - Sound yang digunakan } \\
\text { - Ucapanterimakasih }\end{array}$ \\
\hline 4 & 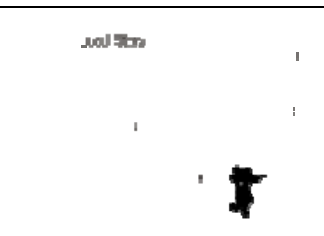 & $\begin{array}{l}\text { Intro Scene } \\
\text { Berisi : } \\
\text { - Judul game story } \\
\text { - Urutan alur cerita }\end{array}$ \\
\hline 5 & $\begin{array}{cc} & \text { H[LP } \\
\cdots & \vdots \\
\cdots & \vdots\end{array}$ & $\begin{array}{l}\text { Help Scene } \\
\text { Tidak di isi dengan audio } \\
\text { Berisi icon yang terdapat pada aplikasi game beserta } \\
\text { keterangannya. }\end{array}$ \\
\hline 6 & i & $\begin{array}{l}\text { Level } 1 \\
\text { Pada semua level menggunakan Sound Jungle Indian } \\
\text { Soundtrack } \\
\text { Latar level } 1 \text { bertemakan hutan di pagi hari } \\
\text { Berisi : } \\
\text { - Indikator jumlah nyawa player } \\
\text { - Indikator jumlah bom player } \\
\text { - Tampilan skor yang terkumpul } \\
\text { - Tombol pause } \\
\text { - Tombol left } \\
\text { - Tombol right } \\
\text { - Tombol jump } \\
\text { - Tombol bom untuk menyerang musuh }\end{array}$ \\
\hline
\end{tabular}




\begin{tabular}{|c|c|c|}
\hline No & Scene & Keterangan \\
\hline & & $\begin{array}{l}\text { - Terdapat koin sebagai dasar perhitungan skor } \\
\text { - Terdapat gambar bom di area sekitar gajah berlari } \\
\text { sebagai bantuan untuk menambah jumlah } \\
\text { persediaan bom } \\
\text { Pada level } 1 \text { pemain akan dihadapkan dengan musuh } \\
\text { monyet yang melempari player dengan batu. } \\
\text { Player dapat menyerang musuh menggunakan bom. } \\
\text { Jika sudah sampai pada skor 200, player akan masuk } \\
\text { ke level } 2 \text {. }\end{array}$ \\
\hline 7 & if & $\begin{array}{l}\text { Level } 2 \\
\text { Latar di sore hari. } \\
\text { Pada level } 2 \text { player akan dihadapkan pada srigala } \\
\text { yang menyerang menggunkan pisau besar dan tajam. } \\
\text { Jika jumlah nyawa player berada dibawah } 50 \% \text { maka } \\
\text { secara otomatis akan ada bantuan power up berupa } \\
\text { gambar apel. } \\
\text { Jika sudah sampai pada skor 500, player akan masuk } \\
\text { ke level } 3 .\end{array}$ \\
\hline 8 & 4 & $\begin{array}{l}\text { Level } 3 \\
\text { Latar di malam hari. } \\
\text { Pada level } 3 \text { player dihadapkan dengan musuh giant } \\
\text { yang bernama kingkong. Musuh ini sangat kejam, dia } \\
\text { dapat memukul, menendang, dan melakukan } \\
\text { serangan spesial yang berakibat pada berkurangnya } \\
\text { nyawa player begitu banyak. } \\
\text { Jika berhasil melewati seluruh kingkong dan skor } \\
\text { yang didapatkan diatas } 700 \text { maka player dinyatakan } \\
\text { menang. }\end{array}$ \\
\hline 9 & Game 0 & $\begin{array}{l}\text { Game Over Scene } \\
\text { Berisi skor baru dan skor lama sebagai perbandingan } \\
\text { nilai. } \\
\text { Terdapat action (tap) jika ingin mengulang game. } \\
\text { Scene ini akan muncul jika player mati karena } \\
\text { tercebur kedalam air atau terbunuh oleh serangan } \\
\text { musuh. }\end{array}$ \\
\hline 10 & & $\begin{array}{l}\text { Win Game Scene } \\
\text { Berisi skor baru dan skor lama. } \\
\text { Terdapat action (tap) jika ingin mengulang game. } \\
\text { Scene ini muncul jika player berhasil mengalahkan } \\
\text { seluruh musuh }\end{array}$ \\
\hline
\end{tabular}

b. Desain Game

Desain Game diawali dengan sketsa background sebagai setting latar permainan yang dirancang menggunakan Coreldraw X4, seperti gambar dibawah ini: 


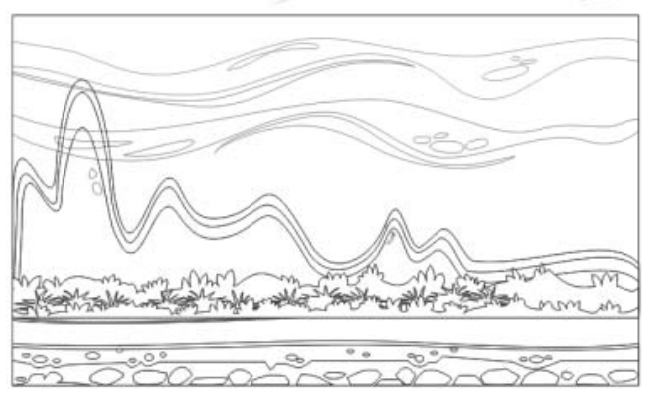

Gambar 1. Desain Background

Selain itu desain game akan ditambahkan dengan elemen pendukung atau yang sering disebut dengan enviorment.

c. Desain Karakter

Pembuatan karakter menggunakan CorelDraw X4 dengan model animation sprite, yang digambar tiap gerakan frame by frame yang tampak seperti dibawah ini:

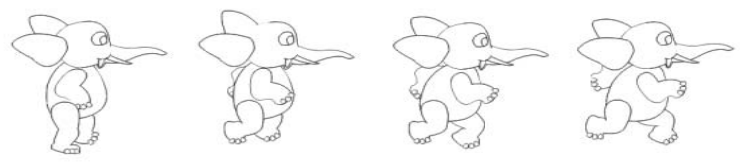

Gambar 2. Desain Karakter Utama
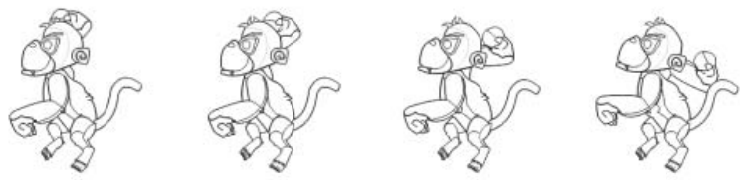

Gambar 3. Desain Karakter Musuh

\subsection{Production}

a. Jenis Musuh

Dalam permainan yang akan dirancang pada penelitian ini, player berhadapan dengan musuh sebagai berikut:

Tabel 2. Rincian Tipe Musuh, Nama dan Tampilannya.

\begin{tabular}{|c|c|c|}
\hline Tipe & Nama & Gambar \\
\hline Penyerang & Joger & \\
\hline Penembak & Khero & \\
\hline Giant & King Kong \\
\hline
\end{tabular}


Terdapat 3 tipe musuh dalam permainan ini yaitu :

- Penyerang

Memiliki sifat agresif. Mereka akan maju sebagai front-liner musuh sebagai penyerang jarak dekat.

- Penembak

Memiliki sifat tidak agresif, menembakan peluru dari kejauhan.

- Giant

Memiliki sifat agresif, musuh tipe giant memiliki karakteristik serangan kuat, nyawa banyak, namun geraknya lambat.

b. Variabel Penentu Perilaku Musuh

Dalam logika fuzzy yang dirancang ini, terdapat 3 variabel linguistik sebagai penentu perilaku musuh yaitu ammo, health dan distance. Pada bagian ini juga akan dirinci variable mana saja yang akan dipakai oleh setiap tipe musuh, misalnya tipe penyerang hanya menggunakan 2 variabel input yaitu distance dan health.

Berikut ini 3 variabel penentu tersebut, dan juga fungsi keanggotaanya :

- Variabel Ammo

Ammo atau istilah untuk amunisi dari batu yang akan dilemparkan monyet untuk menyerang player. Jumlah ammo merupakan angka bulat dengan nilai antara $0-10$.

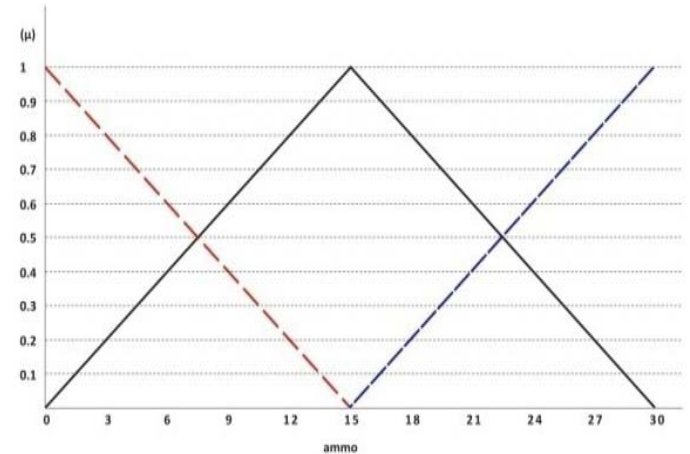

Gambar 4. Fungsi Keanggotaan Ammo

- Variabel Health

Jumlah health merupakan angka bulat. Variable health_max merupakan health (nyawa) maksimal yang dimiliki oleh jenis musuh tertentu.

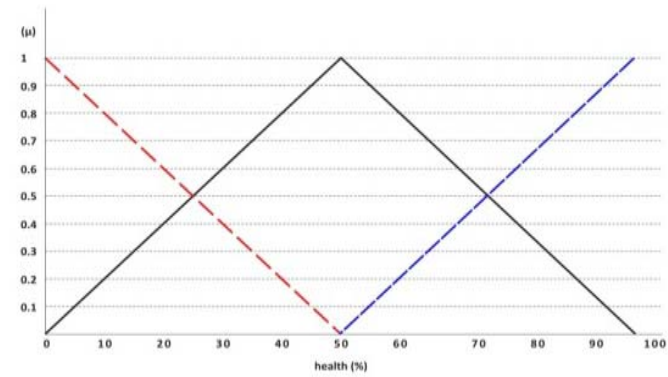

Gambar 5. Fungsi Keanggotaan Health 
- Variabel Distance

Distance merupakan jarak pemain terhadap musuh, dalam meter. Berikut ini adalah fungsi keanggotaan untuk distance.

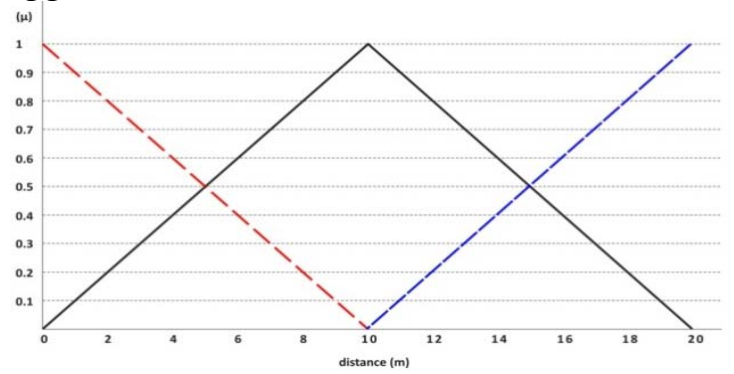

Gambar 6. Fungsi Keanggotaan Distance

Input variable penentu perilaku tersebut nantinya akan menentukan musuh akan bertindak bagaimana. Perilaku musuh terbagi dalam 5 kategori yaitu :

- Melarikan Diri/Lari (range 0-20)

- Bertahan (range 21-40)

- Ragu-ragu (range 41-60)

- Menyerang (range 61-80)

- Menyerang brutal (range 81-100)

Diagram output untuk perilaku musuh terlihat pada gambar berikut ini:

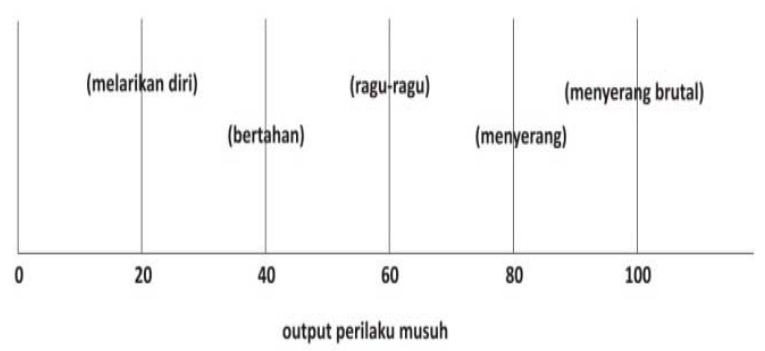

Gambar 7. Diagram Perilaku Musuh

Rule pada setiap tipe musuh ditentukan masing-masing dengan tingkat kesulitan yang berbeda, berikut adalah rule dari ketiga musuh :

- Fuzzy rule untuk musuh penyerang :

- IF distance_near AND health_few THEN lari

- IF distance_near AND health_med THEN bertahan

- IF distance_near AND health_much THEN menyerang

- IF distance_med AND health_few THEN lari

- IF distance_med AND health_med THEN bertahan

- IF distance_med AND health_much THEN menyerang

- IF distance_far AND health_few THEN bertahan

- IF distance_far AND health_med THEN menyerang

- IF distance_far AND health_much THEN brutal

- Fuzzy rule untuk musuh penembak :

- IF distance_near AND ammo_little THEN lari

- IF distance_near AND ammo_med THEN lari 
- IF distance_near AND ammo_many THEN lari

- IF distance_med AND ammo_little THEN bertahan

- IF distance_med AND ammo_med THEN ragu

- IF distance_med AND ammo_many THEN ragu

- IF distance_far AND ammo_little THEN menyerang

- IF distance_far AND ammo_med THEN menyerang

- IF distance_far AND ammo_many THEN menyerang

- Fuzzy rule untuk musuh giant :

- IF distance_near AND health_few THEN bertahan

- IF distance_near AND health_med THEN menyerang

- IF distance_near AND health_much THEN brutal

- IF distance_med AND health_few THEN bertahan

- IF distance_med AND health_med THEN brutal

- IF distance_med AND health_much THEN brutal

- IF distance_far AND health_few THEN menyerang

- IF distance_far AND health_med THEN brutal

- IF distance_far AND health_much THEN brutal

Keseluruhan proses logika fuzzy dapat diterangkan sebagai berikut:

- Fuzzyfikasi Input : Mencari derajat keanggotaan dari input fuzzy yang memenuhi fuzzy rule.

- Operasi Fuzzy : Menggunakan fungsi AND yaitu mengambil nilai MAX dari derajat keanggotaan setiap input fuzzy.

- Implikasi : Mendapatkan keluaran dari fuzzy rule menggunakan fungsi MIN.

- Agregasi : Mengkombinasikan keluaran semua fuzzy rule menjadi fuzzy set tunggal dengan menggunakan fungsi MAX.

- Hasil Fuzzy : Menghasilkan nilai perilaku musuh, antara skala 0-100 dengan metode weighted average. Nilai 0-100 ini nantinya menentukan peluang musuh menyerang pemain.

\section{c. Proses Fuzzy}

Operasi Logika fuzzy yang digunakan pada penelitian ini adalah menggunakan fungsi AND (fungsi MIN). Proses fuzzyfikasi yang digunakan adalah FIS tipe Sugeno berorder nol, karena fuzzy Sugeno menghasilkan konstanta tegas, sehingga dapat mewakili nilai perilaku yang telah di rancang. Proses implikasi menggunakan fungsi MIN, dan agregasi menggunakan fungsi MAX. kemudian hasil fuzzy dihitung dengan weighted average, yaitu dengan rumus:

$$
\text { output }=\frac{\sum_{i=1}^{N} W i Z i}{\sum_{i=1}^{N} W i}
$$

Jika mengambil contoh musuh tipe penyerang, dengan keadaan saat ini miliki health $70 \%$ dan distance 16 meter dari pemain, maka rule yang memenuhi adalah

- IF distance_med AND health_med THEN bertahan

- IF distance_med AND health_much THEN menyerang

- IF distance_far AND health_med THEN menyerang

- IF distance_far AND health_much THEN brutal 
Berdasarkan contoh tersebut dapat dilihat diagram hasil perhitungan yaitu:

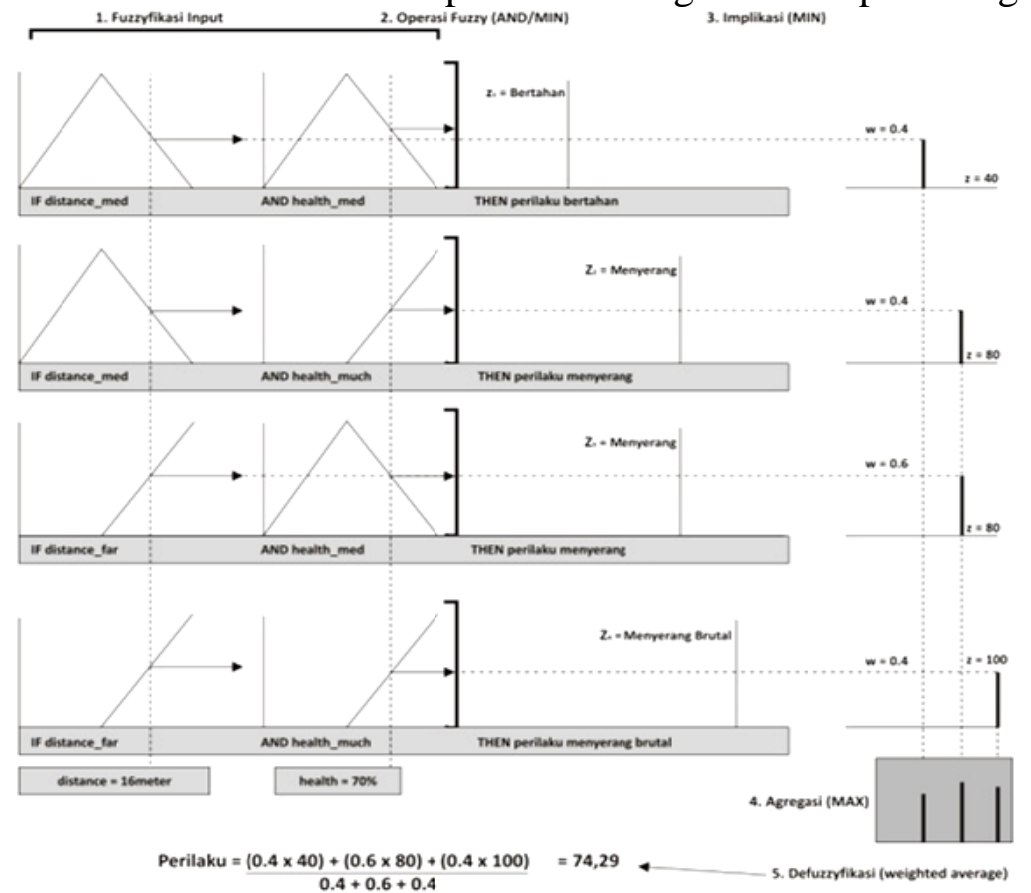

Gambar 8. Diagram Proses Fuzzy

Proses perhitungan fuzzy dengan dijabarkan maupun dengan diagram diatas terlihat bahwa hasilnya 74, berarti musuh penyerang yang memiliki distance (jarak ke player) 16 meter dan health (nyawa) 70\% memiliki peluang 74\% untuk maju menyerang pemain, dan 26\% untuk mundur.

d. Hasil Pengujian Fuzzy

- $\quad$ Penyerang (perhitungan menggunakan variabel health dan distance)

Tabel 3. Hasil Pengujian perilaku Penyerang.

\begin{tabular}{|c|c|c|c|c|c|c|c|c|c|c|c|}
\hline \multicolumn{12}{|c|}{ HASIL PENGUJIAN PERILAKU PENYERANG } \\
\hline health $(\%)$ & 0 & 2 & 4 & 6 & 810 & & 14 & 16 & 18 & 20 & \\
\hline 0 & 20 & 20 & 20 & 20 & 2020 & 24 & 28 & 32 & 36 & & 40 \\
\hline 10 & 24 & 24 & 25 & 25 & 2424 & 33 & 37 & 40 & 43 & & 48 \\
\hline 20 & 28 & 28 & 28 & 28 & 2828 & 37 & 43 & 46 & 55 & & 56 \\
\hline 30 & 32 & 32 & 32 & 32 & 3232 & 45 & 46 & 51 & 57 & & 64 \\
\hline 40 & 36 & 36 & 35 & 34 & 3636 & 49 & 50 & 57 & 63 & & 72 \\
\hline 50 & 40 & 40 & 40 & 40 & 4040 & 48 & 56 & 64 & 72 & & 80 \\
\hline 60 & 48 & 48 & 50 & 50 & 4848 & 65 & 63 & 70 & 77 & & 84 \\
\hline 70 & 56 & 56 & 56 & 56 & 5656 & 73 & 85 & 74 & 80 & & 88 \\
\hline 80 & 64 & 64 & 64 & 64 & 6464 & 70 & 74 & 77 & 83 & & 92 \\
\hline 90 & 72 & 72 & 70 & 68 & 7272 & 77 & 80 & 83 & 87 & & 96 \\
\hline 100 & 80 & 80 & 80 & 80 & 8080 & 84 & 88 & 92 & 96 & & 100 \\
\hline
\end{tabular}

Dari tabel diatas, terlihat bahwa perilaku penyerang adalah :

- Melarikan diri : 5\% (6 dari 121 data)

- Bertahan : 32\% (39 dari 121 data)

- Ragu-ragu : 22\% (27 dari 121 data)

- Menyerang : 30\% (36 dari 121 data) 
- Menyerang Brutal : 11\% (13 dari 121 data)

- Penembak (perhitungan menggunakan variabel distance dan ammo)

Tabel 4. Hasil Pengujian perilaku Penembak.

\begin{tabular}{|c|c|c|c|c|c|c|c|c|c|c|c|}
\hline \multicolumn{10}{|c|}{ HASIL PENGUJAN PERILAKU PELEMPAR } \\
\hline distance (m) & $\mathbf{0}$ & $\mathbf{2}$ & $\mathbf{4}$ & $\mathbf{6}$ & $\mathbf{8}$ & $\mathbf{1 0}$ & $\mathbf{1 2}$ & $\mathbf{1 4}$ & $\mathbf{1 6}$ & $\mathbf{1 8}$ & $\mathbf{2 0}$ \\
\hline 0 & 20 & 24 & 28 & 32 & 36 & 40 & 48 & 56 & 64 & 77 & 80 \\
\hline 1 & 20 & 30 & 33 & 37 & 38 & 44 & 50 & 57 & 63 & 73 & 80 \\
\hline 2 & 20 & 32 & 37 & 40 & 43 & 48 & 53 & 57 & 63 & 68 & 80 \\
\hline 3 & 20 & 32 & 37 & 43 & 47 & 52 & 57 & 80 & 80 & 68 & 80 \\
\hline 4 & 20 & 30 & 37 & 43 & 50 & 56 & 60 & 65 & 67 & 73 & 74 \\
\hline 5 & 20 & 28 & 36 & 44 & 52 & 60 & 60 & 68 & 72 & 76 & 80 \\
\hline 6 & 20 & 28 & 36 & 44 & 52 & 60 & 64 & 69 & 72 & 76 & 80 \\
\hline 7 & 20 & 30 & 36 & 44 & 51 & 60 & 64 & 68 & 72 & 72 & 80 \\
\hline 8 & 20 & 30 & 36 & 44 & 60 & 60 & 66 & 68 & 72 & 72 & 80 \\
\hline 9 & 20 & 32 & 39 & 44 & 52 & 60 & 62 & 68 & 73 & 76 & 80 \\
\hline 10 & 20 & 28 & 36 & 44 & 52 & 60 & 60 & 68 & 72 & 76 & 80 \\
\hline
\end{tabular}

Dari tabel diatas, terlihat bahwa perilaku penembak adalah :

- Melarikan diri : 9\% (11 dari 121 data)

- Bertahan : 23\% (28 dari 121 data)

- Ragu-ragu : 31\% (38 dari 121 data)

- Menyerang : 36\% (44 dari 121 data)

- Menyerang Brutal : 0\% (0 dari 121 data)

Giant (perhitungan menggunakan variable distance dan health)

Tabel 5. Hasil Pengujian perilaku Giant.

\begin{tabular}{|c|c|c|c|c|c|c|c|c|c|c|c|}
\hline $\begin{array}{c}\text { distance } \\
(\mathrm{m})\end{array}$ & 0 & 2 & 4 & 6 & 8 & 10 & 12 & 14 & 16 & 18 & 20 \\
\hline $\begin{array}{c}\text { health } \\
(\%)\end{array}$ & & & & & & & & & & & \\
\hline 0 & 40 & 40 & 40 & 40 & 40 & 40 & 48 & 56 & 64 & 72 & 80 \\
\hline 10 & 48 & 57 & 60 & 60 & 57 & 52 & 57 & 63 & 70 & 77 & 84 \\
\hline 20 & 56 & 63 & 69 & 69 & 67 & 64 & 67 & 69 & 74 & 80 & 88 \\
\hline 30 & 64 & 70 & 74 & 77 & 77 & 76 & 77 & 77 & 77 & 83 & 92 \\
\hline 40 & 72 & 77 & 80 & 83 & 87 & 88 & 87 & 84 & 84 & 87 & 96 \\
\hline 50 & 80 & 84 & 88 & 92 & 96 & 100 & 100 & 100 & 100 & 100 & 100 \\
\hline 60 & 84 & 84 & 88 & 92 & 96 & 100 & 100 & 100 & 100 & 100 & 100 \\
\hline 70 & 88 & 88 & 88 & 92 & 95 & 100 & 100 & 100 & 100 & 100 & 100 \\
\hline 80 & 92 & 92 & 92 & 92 & 95 & 100 & 100 & 100 & 100 & 100 & 100 \\
\hline 90 & 96 & 96 & 95 & 95 & 96 & 100 & 100 & 100 & 100 & 100 & 100 \\
\hline 100 & 100 & 100 & 100 & 100 & 100 & 100 & 100 & 100 & 100 & 100 & 100 \\
\hline
\end{tabular}

Dari tabel diatas, terlihat bahwa perilaku giant adalah :

- Melarikan diri : 0\% (0 dari 121 data)

- Bertahan : 5\% (6 dari 121 data)

- Ragu-ragu : 8\% (10 dari 121 data)

- Menyerang : 23\% (28 dari 121 data)

- Menyerang Brutal : 64\% (77 dari 121 data)

e. Implementasi Sistem

- Pembuatan Scene Game 
Langkah awal pembuatan scene menggunaka Unity 3D ini adalah dengan menyusun objek-objek yang sudah dibuat sesuai dengan konsep seperti sprite player, background dan objek-objek pendukung lainnya seperti power up, bom maupun enviorment tanah dan air.

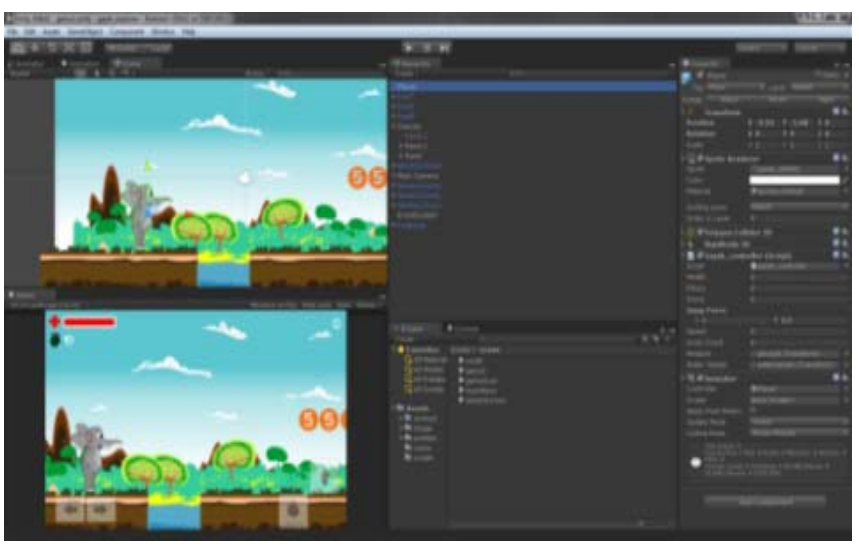

Gambar 9. Pembuatan Arena Game

- Proses build game

Game yang sudah jadi akan di build ke file berekstensi ‘.apk’ agar dapat diinstall ke android.

\subsection{Post-Production}

a. Publish ke Play Store

APK yang sudah dibuat kemudian dapat diupload ke Play Store. Jika berhasil maka akan keluar jendela konfigurasi produksi atau kelengkapan informasi tentang APK tersebut dan aplikasi sudah berhasil terpasang.

Proses instalasi aplikasi menggunakan smarthphone android cukup mudah dengan download via Play Store kemudian install. Berikut adalah tampilan game di smarthphone yang akan dimainkan

Tampilan level game seperti pada Gambar 10, Gambar 11 dan Gambar 12 , perbedaan masing-masing level adalah rintangan yang dihadapi.

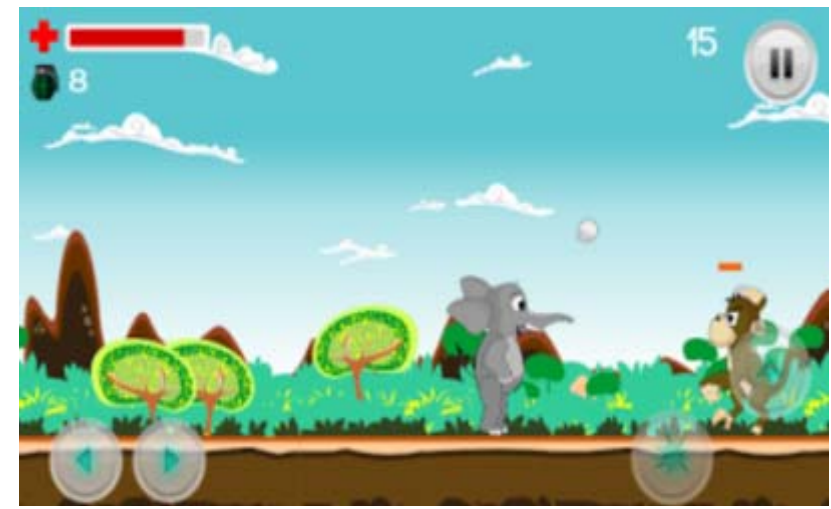

Gambar 10. Tampilan Level 1 


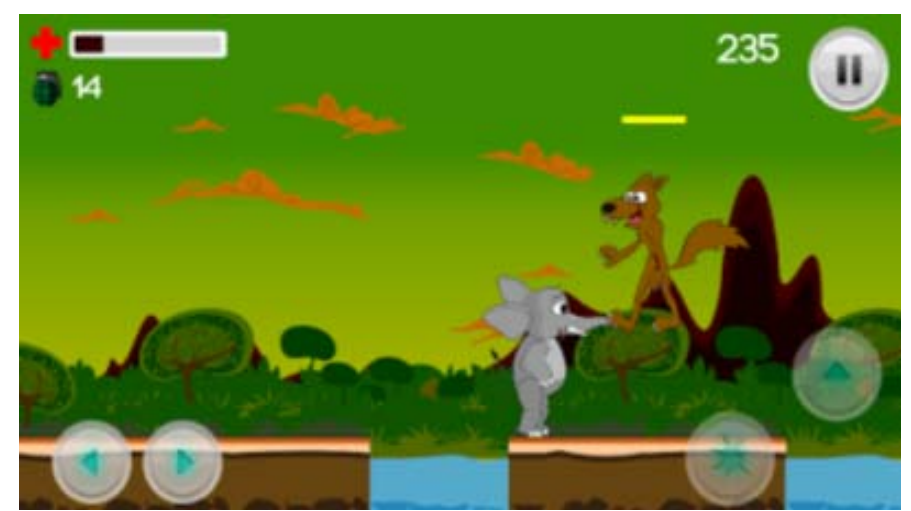

Gambar 11. Tampilan Level 2

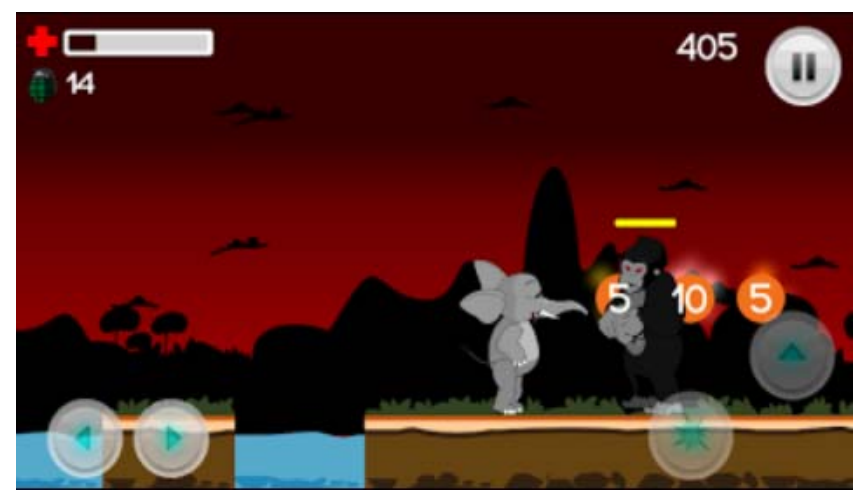

Gambar 12. Tampilan Level 3

b. Pengujian dengan Balckbox

- Scene

- Splash Screen: Splash Screen muncul,saat awal game dijalankan

- Main Menu: Main menu muncul, setelah splash screen

- Credit Screen: Muncul, jika tombol credit screen ditekan pada main menu

- Intro Game: Muncul, jika tombol Intro ditekan pada mainmenu

- Game Over : Muncul, jika player tercebur atau diserang musuh hingga nyawanya habis

- Game Win: Muncul, jika player berhasil mengalahkan musuh sampai kingkong tuntas

- Player Animasi

- Berlari: Berjalan, sejak awal game dimainkan

- Melompat: Berjalan, jika mendapatkan inputan tap

- Animasi Musuh

- Monyet: Berjalan, sejak awal game dimainkan

- Serigala: Bergerak setelah player berhasil mengalah-kan monyet

- Kingkong: Bergerak setelah player berhasil mengalah-kan monyet dan srigala

- Sound

- Back sound: Berbunyi, sejak awal game dimainkan

- Duarr: Berbunyi, ketika player melempar bom ke musuh

- Suara Percikan Air: Berbunyi, ketika player atau musuh tercebur ke dalam air 
- Main Music: Berbunyi, ketika main menu muncul

- Button

- Play : Berfungsi, dan untuk masuk ke arena game

- Credit : Berfungsi, dan untuk masuk ke tampilan credit screen

- Quit : Berfungsi, dan untuk keluar game

- Pause : Berfungsi, dan untuk menghenti-kan game sementara

- Play : Berfungsi, dan untuk memainkan game kembali

- Grafis

- Tampilan Game: Bagus, seluruh desain tampil dan memenuhi layar

- Resolusi Layar: Bagus, game dapat dijalankan pada beberapa jenis resolusi layar

- Game Play

- Inputan Player: Berfungsi, jika player Tap layar akan menggerak-kan karakter player

- Gerakan Musuh: Berfungsi, seluruh musuh bergerak sesuai script yang diberikan.

- Gerakan Objek: Berfungsi, seluruh objek bergerak sesuai script yang diberikan

- Kecepatan Musuh: Berfungsi, kecepatan musuh sesuai script yang diberikan dimana jika tingkatan bertambah maka kecepatannya pun bertambah

- Indikator Menang: Berfungsi, sesuai script yang diberikan dimana jika player menemukan anaknya maka game win akan muncul

- Indikator Game Over: Berfungsi, sesuai script yang diberikan dimana player tercebur atau nyawanya habis

c. Pengujian Device

Permainan ini dirancang dan diujicoba ke device dengan spesifikasi :

Tabel 6. Uji Device Menggunakan Tabel t

\begin{tabular}{|c|c|c|}
\hline \multirow{8}{*}{$\begin{array}{l}\text { TABELT } \\
\text { EVERCOSS } \\
\text { W7B } \\
\text { Android OS, } \\
\text { v4.4.4 (KitKat) } \\
\text { Prosesor Quad } \\
\text { Core 1,3GHz } \\
\text { Resolusi 480x800 } \\
\text { pixels, } 7 \text { inches } \\
\text { 512MB RAM }\end{array}$} & Animasi & Seluruh animasi berjalan lancar \\
\hline & Audio & Seluruh audio berjalan dengan baik \\
\hline & Tombol & Seluruh tombol fungsi berfungsi dengan baik \\
\hline & Grafis & $\begin{array}{l}\text { resolusi gambar terlihat jelas pada resolusi } \\
\text { 480x800 px, tanpa ada sisi kosong }\end{array}$ \\
\hline & $\begin{array}{l}\text { Screen } \\
\text { play }\end{array}$ & screenplay berjalan baik \\
\hline & $\begin{array}{l}\text { Game } \\
\text { play }\end{array}$ & $\begin{array}{l}\text { tidak ditemukan bug secara kesuluruhan game } \\
\text { berjalan lancar }\end{array}$ \\
\hline & $\begin{array}{c}\text { Smooth } \\
\text { ness }\end{array}$ & $\begin{array}{l}\text { berjalan kurang begitu lancar /terkadang terjadi } \\
\text { lag namun tidak menganggu }\end{array}$ \\
\hline & Memory & $\begin{array}{l}\text { Ketika menginstall game maka memakan } \\
\text { memory sebesar } 17.87 \mathrm{MB}\end{array}$ \\
\hline
\end{tabular}




\section{d. Pengujian dengan Kuesioner}

Tabel 7. Hasil Pengujian Tiap Aspek

\begin{tabular}{|r|l|c|}
\hline No & \multicolumn{1}{|c|}{ Aspek Penguji Game } & Hasil (\%) \\
\hline 1 & Tampilan game dan animasi menarik & 87.9 \\
\hline 2 & Audio sesuai dengan aksi atau scene yang sedang berjalan & 95.0 \\
\hline 3 & $\begin{array}{l}\text { Cerita atau konsep dalam game ini sesuai dengan game yang } \\
\text { sedang dimainkan }\end{array}$ & 79.3 \\
\hline 4 & Bahasa dalam aplikasi game ini mudah dipahami & 92.9 \\
\hline 5 & Penggunaan warna dan desain background sudah sesuai & 90.7 \\
\hline 6 & Ketetapan ukuran, warna, dan pemilihan jenis tulisan sesuai & 81.4 \\
\hline 7 & Ukuran, warna, dan bentuk tombol pada game sudah sesuai & 79.3 \\
\hline 8 & Ketetapan fungsi tombol dengan tujuan yang di inginkan sesuai & 87.1 \\
\hline 9 & Kesesuaian ukuran dan warna karakter & 92.9 \\
\hline 10 & Kemudahan pengoperasian game & 89.3 \\
\hline
\end{tabular}

Dari hasil pengujian diketahui bahwa 28 responden memberikan penilaian terhadap game "Single Fighter" memiliki keunggulan dalam bentuk karakter, desain background dari animasi yang sesuai dengan tema dengan bahasa yang mudah dipahami serta efek sound berjalan dengan baik. Kelemahan dari game ini adalah terletak pada ceritanya yang tidak banyak menampilkan kisah sebelumnya dalam bentuk animasi serta penampilan tombol yang samar.

\section{KESIMPULAN}

\subsection{Kesimpulan}

Dari hasil pembuatan dan pengujian game "Single Fighter", dapat ditarik kesimpulan sebagai berikut :

1. Logika Fuzzy dapat diterapkan untuk mengatur perilaku musuh. Perilaku ini ditentukan dari jarak musuh ke player (distance), amunisi (ammo) dan nyawa musuh (health).

2. Penerapan fuzzy dalam permainan ini telah berjalan dengan baik, dimana musuh tipe penyerang menjadi cukup agresif (30\% perilaku menyerang, 11\% menyerang brutal), tipe penembak agresif jika berada pada jarak jauh (36\% perilaku menyerang), dan musuh giant sangat agresif (23\% perilaku menyerang, 64\% perilaku menyerang brutal).

3. Aplikasi game "Single Fighter" berhasil di publish di Google Play Store yang dibuat dari game engine Unity, ber-genre side scrolling game, dan berplatform android.

4. Aplikasi game "Single Fighter", dapat dijalankan pada berbagai macam smartphone berbasis Android dengan spesifikasi minimum RAM 512MB, CPU single core $1 \mathrm{Ghz}$, resolusi 320 x 480 px.

\subsection{Saran}

Berdasarkan kesimpulan diatas, maka saran yang dapat penulis berikan agar aplikasi dapat dikembangkan menjadi lebih baik dengan cara :

1. Penambahan variable input untuk fuzzy, misalnya musuh yang menyerang tidak hanya satu, atau jika rekan musuh nyawanya melemah, musuh yang lain langsung datang membantu menyerang.

2. Ditambahkan objek-objek animasi yang lebih menarik 
3. Pengembangan cerita yang lebih kompleks dan variatif sehingga game akan memiliki umur yang cukup panjang.

\section{DAFTAR PUSTAKA}

Al Hasmy, R. (2011 ). Penentuan Peran Dalam Robot Sepak Bola Dengan Metode Fuzzy Sugeno. Jurnal ITS Surabaya .

Kusumadewi, S. (2010). Aplikasi Logika Fuzzy Untuk Pendukung Keputusan Edisi 2. Yogyakarta: Graha Ilmu.

Purba, R. (2013). Implementasi Logika Fuzzy Untuk Mengatur Perilaku Musuh Dlaam Game Bertipe Action-RPG . Jurnal EECCISVol.7, No.1 .

Wahana Komputer. (2013). Step by Step Menjadi Programmer Android. Semarang: Andi Publisher.

Watkins, A. (2011 ). Creating Games with Unity and Maya . Burlington: Elsevier Inc. 